Gut, 1985, 26, 151-157

\title{
Familial occurrence of complement dysfunction in Crohn's disease: correlation with intestinal symptoms and hypercatabolism of complement
}

\author{
J ELMGREEN, H BOTH, AND V BINDER \\ From the Medical Department C, Herlev Hospital, University of Copenhagen, Copenhagen, Denmark
}

SUmmary Complement was studied in Crohn's disease probands with early onset and in their first degree relatives. Controls included 24 healthy volunteers and 24 patients with ulcerative colitis or peptic ulcers. Subnormal generation of chemotactic activity by the alternative pathway was shown in eight of 21 probands and in six of 33 relatives, a frequency in both groups significantly different from controls $(\mathrm{p}<0.005)$, with a strong connection between findings in patients and relatives. As previously shown in patients with Crohn's disease, the subnormal generation was related to decreased utilisation of complement $\mathrm{C} 3$ in relatives. Raised levels of circulating complement $\mathrm{C} 3 \mathrm{c}$ split products suggested complement involvement in Crohn's disease probands. In contrast, plasma $\mathrm{C} 3 \mathrm{c}$ was normal in all relatives, and none of the six cases with complement dysfunction had gastrointestinal symptoms or a history of inflammatory bowel disease. Our data suggest, that complement abnormality seen in Crohn's disease patients does not simply reflect mucosal inflammation or hypercatabolism of complement.

A significant abnormality of complement has previously been shown in Crohn's disease. Release of chemotactic activity for neutrophils, ${ }^{12}$ elicited via $\mathrm{C} 5 \mathrm{a}^{2}$ from complement, is subnormal, the defective function being confined to the alternative pathway. ${ }^{3}$ Increases of complement $\mathrm{C} 3$ catabolism in vivo, ${ }^{4}$ raised levels of circulating complement $\mathrm{C} 3 \mathrm{c}$ split products ${ }^{5}$ and positive immunoconglutinin titres ${ }^{6}$ all suggest involvement of complement in Crohn's disease.

In chronic granulomatous disease the primary dysfunction of phagocytic cells produces histologic changes of the gut, closely resembling those seen in Crohn's disease. ${ }^{7}$ This similarity stresses the potential significance of an inappropriate capacity for complement activation of neutrophils in Crohn's disease.

The aim of the present study was to define the nature of complement abnormality in Crohn's disease by a family study. Familial aggregation of chronic inflammatory bowel disease has been shown in several investigations ${ }^{8}$ and seems to be associated with early onset of the disease. ${ }^{9} 10$

Address for correspondence: J Elmgreen, MD, Medical Gastroenterological Department C 107, Herlev University Hospital, DK-2730 Herlev, Denmark. Received for publication 24 April 1984

\section{Methods}

PATIENTS

A total of 21 patients with Crohn's disease, with an onset before the age of 21 years, were chosen as probands from our regional outpatient clinic. First degree relatives, aged 15-60 years were invited to participate.

The study was joined by all of 33 such family members of 16 probands living in the regional area. Five patients had no close relatives or they refused to accept family members' participation in the study.

Normal controls comprised 24 healthy volunteers, nine men and 15 women, aged 23-63 years. Disease controls included 12 consecutive outpatients with ulcerative colitis and 12 with peptic ulcers. The clinical data are given in Table 1 . None of the subjects investigated had complicating infections, rheumatic disease, or conditions affecting the immune system such as atopy.

In a preliminary part of the study, optimal experimental conditions were defined through investigations of 12 Crohn's disease patients (Table 1) and 12 healthy volunteers.

All patients, relatives, and normal controls gave informed consent to participate. Our protocol has been accepted by the regional scientific-ethical 
Table 1 Clinical parameters in patients with Crohn's disease (CD) and in disease controls with ulcerative colitis (UC) and peptic ulcers $(P U)$.

\begin{tabular}{|c|c|c|c|c|c|c|c|c|c|c|c|}
\hline & \multirow[b]{2}{*}{ Age $(y r)^{*}$} & \multirow[b]{2}{*}{ Sex } & \multirow[b]{2}{*}{ Duration* } & \multicolumn{2}{|l|}{ Activity ${ }^{+}$} & \multicolumn{3}{|c|}{ Involvement } & \multicolumn{2}{|c|}{ Treatment } & \multirow[b]{2}{*}{ Resection(s) } \\
\hline & & & & Quiescent & Active & Ileum & $\begin{array}{l}\text { Ileum and } \\
\text { colon }\end{array}$ & Colon & None & $S A S P \ddagger$ & \\
\hline $\begin{array}{l}\text { CD patients } \\
(n=21)\end{array}$ & $\begin{array}{l}27 \\
(13-45)\end{array}$ & $\begin{array}{r}80^{\prime \prime} \\
130\end{array}$ & $\begin{array}{l}7 \\
(2-32)\end{array}$ & 7 & 14 & 3 & 13 & 5 & 13 & 8 & 14 \\
\hline $\begin{array}{l}\text { UC patients } \\
(n=12)\end{array}$ & $\begin{array}{l}37 \\
(19-70)\end{array}$ & $\begin{array}{l}4 \sigma^{7} \\
8 \%\end{array}$ & $\begin{array}{l}8 \\
(1-13)\end{array}$ & 4 & 8 & - & - & 12 & 12 & 0 & 0 \\
\hline $\begin{array}{l}\text { PU patients } \\
(n=12)\end{array}$ & $\begin{array}{l}43 \\
(30-74)\end{array}$ & $\begin{array}{r}100^{\circ} \\
2 \%\end{array}$ & - & 0 & 12 & - & - & - & 12 & 0 & - \\
\hline $\begin{array}{l}\text { CD patients } \S \\
(n=12)\end{array}$ & $\begin{array}{l}51 \\
(22-73)\end{array}$ & $\begin{array}{l}30^{\prime \prime} \\
9 \%\end{array}$ & $\begin{array}{l}12 \\
(1-17)\end{array}$ & 2 & 10 & 4 & 5 & 3 & 12 & 0 & 6 \\
\hline
\end{tabular}

Diagnostic criteria for patients with chronic inflammatory bowel disease have previously been published. ${ }^{11}$ All patients with peptic ulcers had the diagnosis confirmed by gastroscopy.

* Medians, ranges in parentheses.

$\dagger$ According to Harvey $1980^{12}$ (Crohn's disease) and Binder $1970^{13}$ (ulcerative colitis).

$\ddagger$ Salazosulphapyridine $2-3 \mathrm{~g} / \mathrm{day}$.

$\S$ This group was investigated in a preliminary part of the study.

committee.

Circulating complement was activated by the alternative pathway with subsequent assessment of both chemotactic activity generated and C3 utilisation. Concentrations of $\mathrm{C} 3 \mathrm{c}$ split products were assessed in non-activated plasma.

\section{COMPLEMENT ACTIVATION}

Freshly prepared heparin plasma $(2 \mathrm{IU} / \mathrm{ml})$ and serum were incubated with zymosan A (Sigma, St Louis, USA) at $37^{\circ} \mathrm{C}$, to activate alternative pathway complement. ${ }^{14}$ Non-activated samples served as negative controls. Further, spontaneous activation of complement was prevented with disodium EDTA $(10 \mathrm{mM})$ added immediately after incubation. Zymosan particles were removed by centrifugation..All samples were frozen in liquid nitrogen, stored at $-80^{\circ} \mathrm{C}$, and thawed only once before analysis.

\section{CHEMOTACTIC ACTIVITY}

Generation of chemotactic activity by complement was quantified by the Boyden filter assay ${ }^{15}$ and the leading front technique, which has previously been described in detail. ${ }^{16}$ Leucocyte donors were healthy volunteers of blood type $\mathrm{O} R \mathrm{Rh}$-negative. Test neutrophils were isolated from peripheral blood drawn in disodium EDTA (10 mM) by a methylcellulose sedimentation of the red cells, gradient centrifugation of buffy coat leucocytes on Lymphoprep $^{\circledast 17}$ (Nygaard, Oslo, Norway), and three times washing and resuspension in Gey's solution, including purified human-albumin (20 g/l, Behringwerke, Marburg, FR Germany). The final leucocyte preparation contained $\geqslant 97 \%$ poly- morphonuclear leucocytes, and the median recovery of neutrophils was $45 \%$. Two million cells from this suspension were added to the upper compartment of the modified Boyden chambers and neutrophil chemotaxis was assessed after migration for 45 minutes at $37^{\circ} \mathrm{C}$ in $3 \mu \mathrm{m}$ pore size Sartorius filters. Ten per cent dilutions of the serum and plasma samples in Gey's solution with disodium EDTA (10 $\mathrm{mM}$ ) were added to the lower compartment of the Boyden chambers for assessment of chemotactic activity.

Controls included neutrophil migration towards casein (5 g/l, Alkalilöslich, Merck, Darmstadt, FRG) and Gey's solution with disodium EDTA (10 $\mathrm{mM}$ ). The casein was dissolved in modified Gey's solution for 60 minutes at $\mathrm{pH} 12$ with subsequent lowering of $\mathrm{pH}$ to $7 \cdot 3$. $^{15}$ Samples from Crohn's disease patients with an early onset, their relatives and both groups of controls were tested in each of 21 experiments.

In a preliminary series of experiments 12 Crohn's disease patients and 12 healthy volunteers were studied to define optimal conditions for the activation procedure. Results represent the median of five determinations on each of two filters. Coefficient of variation for the double determinations was $4 \%$.

\section{C3 UTILISATION AND C 3 C LEVElS}

Corresponding pairs of complement activated and non-activated plasma and serum samples were analysed by crossed immunoelectrophoresis on one immuno-plate. ${ }^{2}$ Complete separation of native C3 and its conversion products was achieved by the first run at $20 \mathrm{~V} / \mathrm{cm}$ for 1.5 hours. ${ }^{18}$ The second 
electrophoretic dimension was performed in antibody to C3c (Dakopatts, Copenhagen, Denmark) at $3 \mathrm{~V} / \mathrm{cm}$ for 18 hours. Utilisation of C3 during activation was expressed as percentual decrease of the native $\mathrm{C} 3$ precipitation area.

Native C3 and the c split product of C3 (C3c) were quantified in plasma samples drawn in disodium EDTA, immediately frozen in liquid nitrogen, stored at $-80^{\circ} \mathrm{C}$, and thawed only once, before analysis. Native C3 was assessed by immunoelectrophoresis ${ }^{19}$ in antibody to C3c (Dakopatts) whereas C3c split products were analysed by an intermediate gel technique. ${ }^{20}$ Precipitation of native $\mathrm{C} 3$ and $\mathrm{C} 3$ split products with d specificity was achieved by antibody specific for C3d (Dakopatts) in the intermediate gel. $\mathrm{C} 3 \mathrm{c}$ rockets were formed in the upper gel by precipitation with antibody specific for $\mathrm{C} 3 \mathrm{c}$. A plasma pool served as standard for quantitation of native $\mathrm{C} 3$ whereas standard human serum from Behringwerke, containing $\mathrm{C} 3$ in the form of $\mathrm{C} 3 \mathrm{c}$ only, served as standard in the intermediate gel technique.

\section{STATISTICS}

The result were evaluated by non-parametric statistics: the Mann-Whitney U test, Wilcoxon's test for paired data, the four-fold table test, and Spearman rank correlation test.

\section{Results}

Eight of 21 Crohn's disease probands, and six of their 33 first degree relatives showed subnormal generation of chemotactic activity by the alternative pathway of circulating complement (Fig. 1). Significance was at the $p<0.005$ level, both comparing probands $\left(\chi^{2}=17, \mathrm{df}=1\right)$ and comparing relatives $\left(\chi^{2}=7, \mathrm{df}=1\right)$ with total control group. The chemotactic activity of non-activated samples did not differ between probands, relatives and controls (Table 2). Identical results were obtained with plasma and serum complement in this study (Table 3). Means of results obtained with the two sources of complement are given in Fig. 1.

The six Crohn's disease relatives with
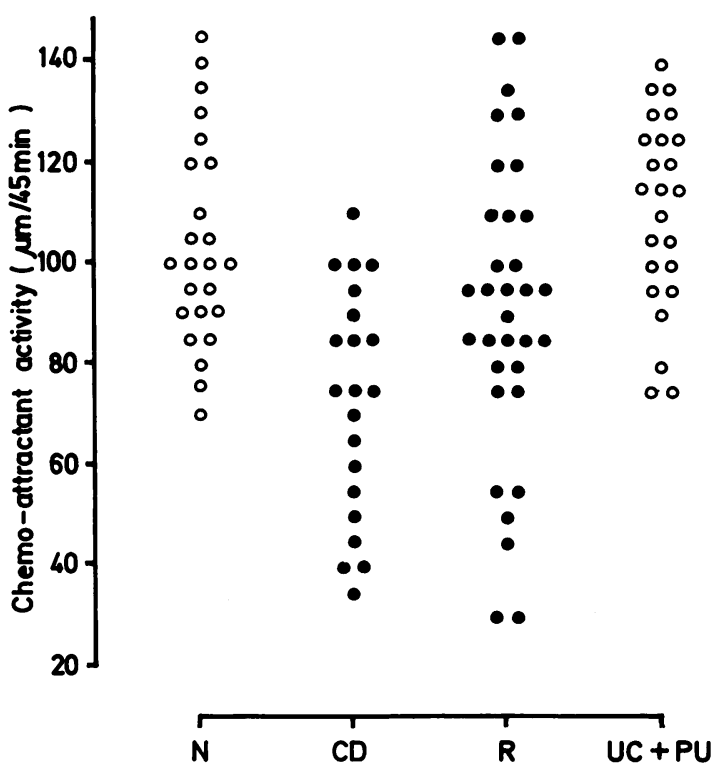

Fig. 1 Generation of chemotactic activity by the alternative pathway of complement in Crohn's disease patients (CD), their first degree relatives $(R)$, normal controls $(N)$, and disease controls with ulcerative colitis (UC) or peptir, ulcers $(P U)$. experimental groups, $\circ$ controls.

complement dysfunction had a decreased utilisation of $\mathrm{C} 3$ by the alternative pathway of complement (Fig. 2), compared with normal and disease controls, and with 27 Crohn's disease relatives showing normal generation of chemotactic activity $(p<0.005)$. Means of identical results from plasma and serum are given. Normal levels of circulating, native C3 in Crohn's disease relatives (Table 4) permitted the $\mathrm{C} 3$ utilisation to be expressed in per cent of $\mathrm{C} 3$ concentrations.

Levels of plasma C3c split products were normal in Crohn's disease relatives and in disease controls with ulcerative colitis and peptic ulcers (Fig. 3) whereas an increase was observed in Crohn's disease patients, versus both normal and disease controls $(p<0.005)$. Neither C3c levels nor chemotactic

Table 2 Chemotactic activity in $\mu \mathrm{m} / 45$ minutes of non-activated plasma and serum samples. Medians with ranges in parentheses.

\begin{tabular}{lllll}
\hline & $\begin{array}{l}\text { Normal controls } \\
(n=24)\end{array}$ & $\begin{array}{l}\text { Crohn's disease probands } \\
(n=21)\end{array}$ & $\begin{array}{l}\text { Crohn's disease relatives } \\
(n=33)\end{array}$ & $\begin{array}{l}\text { Disease controls } \\
(n=24)\end{array}$ \\
\hline Non-activated plasma complement & 34 & 26 & 30 & 31 \\
Non-activated serum complement & $(16-56)$ & $(6-60)$ & $(8-54)$ & $(10-58)$ \\
& $(18-85)$ & 30 & 36 & 33 \\
$(9-84)$ & $(6-98)$ & $(9-8)$ & \\
\hline
\end{tabular}


Table 3 Generation of chemotactic activity in $\mu \mathrm{m} / 45$ minutes by the alternative pathway of plasma and serum complement. Medians with ranges in parentheses.

\begin{tabular}{lllll}
\hline & $\begin{array}{l}\text { Normal controls } \\
(n=24)\end{array}$ & $\begin{array}{l}\text { Crohn's disease patients } \\
(n=21)\end{array}$ & $\begin{array}{l}\text { Crohn's disease relatives } \\
(n=33)\end{array}$ & $\begin{array}{l}\text { Disease controls } \\
(n=24)\end{array}$ \\
\hline Activated plasma complement & 100 & $68^{*}$ & 86 & 106 \\
Activated serum complement & $(72-143)$ & $(20-106)$ & $(19-140)$ & $(70-146)$ \\
& 101 & $74^{*}$ & 94 & 110 \\
$(70-146)$ & $(33-111)$ & $(10-155)$ & $(73-150)$ \\
\hline
\end{tabular}

${ }^{*} \mathrm{p}<0.005$.

activity generated by complement related to disease activity $(\mathrm{p}>0 \cdot 10$, rank correlation test) or to localisation of inflammation $(\mathrm{p}>0 \cdot 10$, rank sum test).

Complement abnormality in Crohn's disease relatives was confined to families of probands with a release of chemotactic activity by complement below or at the lower border of the reference interval (Table 5). The relatives with dysfunction had no symptoms or history of inflammatory bowel disease. The phenomenon occurred both in parents and siblings, in young and middle aged, and in men and women (Table 5). One Crohn's disease relative with complement dysfunction had a previously diagnosed ankylosing spondylitis (Table 5).

In a preliminary part of the investigation the dose response and the time response for generation of chemotactic factors by complement was investigated (Table 6). The optimal sensitivity in the Boyden

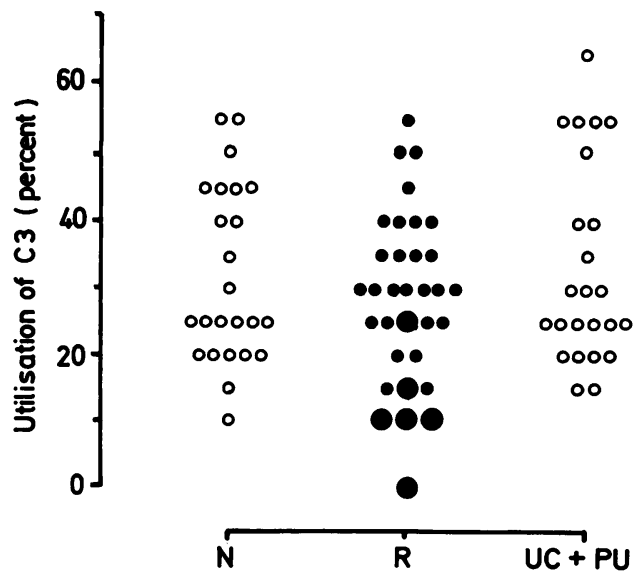

Fig. 2 Utilisation of complement $C 3$ by the alternative pathway of complement in first degree relatives of Crohn's disease patients $(R)$, normal controls $(N)$, and disease controls with ulcerative colitis $(U C)$ or peptic ulcers $(P U)$. relatives with decreased generation of chemotactic activity, $\bullet$ relatives with normal generation, $\bigcirc$ controls. filter assay of chemotactic factor generation was obtained with zymosan $2 \times 10^{-1} \mathrm{~g} / \mathrm{l}$ and incubation time of 60 minutes. These conditions were chosen for the present study. Declining responses with increases of incubation time and zymosan concentrations are consistent with a relation between decreasing responses and supramaximal concentrations of $\mathrm{C} 5 \mathrm{a} .{ }^{21}$ Test neutrophils had a median casein chemotaxis of 135 , range $105-174 \mu \mathrm{m} / 45$ minutes in all experiments, and spontaneous migration towards Gey's solution with EDTA was 37, range 5-65 $\mu \mathrm{m} / 45$ minutes.

\section{Discussion}

Subnormal generation of chemotactic activity by the alternative pathway of complement has previously been shown in unselected patients with Crohn's disease. ${ }^{12}$ This observation was confirmed in the

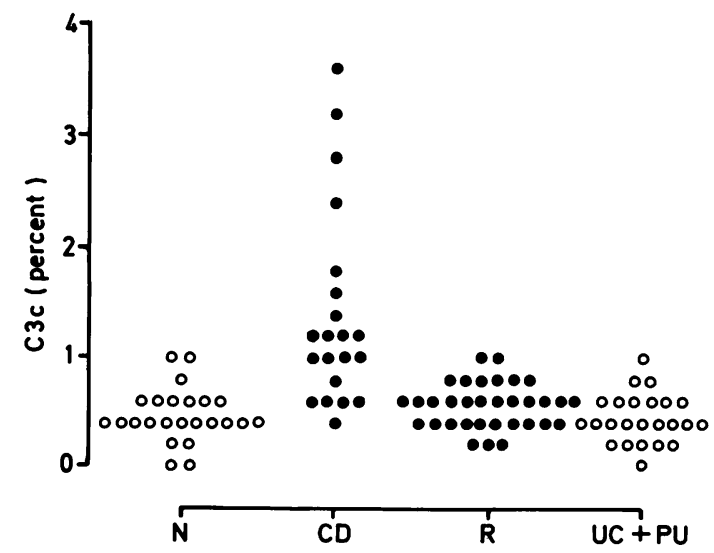

Fig. 3 Plasma concentrations of c split products of complement $\mathrm{C3}(\mathrm{C} 3 \mathrm{c})$ in Crohn's disease patients $(C D)$, their first degree relatives $(R)$, normal controls $(N)$, and disease controls with ulcerative colitis (UC) or peptic ulcers $(P U)$. experimental groups, $\circ$ controls. Values expressed in per cent of a standard human serum containing $C 3$ in the form of C3c only. 
Table 4 Concentrations of native $C 3$ in per cent, medians with ranges in parentheses.

\begin{tabular}{lllll}
\hline & $\begin{array}{l}\text { Normal } \\
\text { controls } \\
(n=24)\end{array}$ & $\begin{array}{l}\text { Crohn's } \\
\text { disease } \\
\text { probands } \\
(n=21)\end{array}$ & $\begin{array}{l}\text { Crohn's } \\
\text { disease } \\
\text { relatives } \\
(n=33)\end{array}$ & $\begin{array}{l}\text { Disease } \\
\text { controls } \\
(n=24)\end{array}$ \\
\hline Plasma C3 & 96 & 101 & 107 & 93 \\
& $(65-142)$ & $(56-148)$ & $(58-153)$ & $(57-125)$ \\
\hline
\end{tabular}

present group of probands with early onset Crohn's disease. A similar defect of complement was revealed in six of their 33 first degree relatives. All members of the subgroup of relatives with complement abnormality had a negative case history of intestinal symptoms and, in contrast with patients, no raised plasma $\mathrm{C} 3 \mathrm{c}$, excluding hypercatabolism of complement in Crohn's disease patients as the explanation. ${ }^{5}$

The unexpected finding of normal $\mathrm{C} 3 \mathrm{c}$ split product levels in ulcerative colitis controls, contrasting $\mathrm{C} 3 \mathrm{c}$ rise in Crohn's disease probands has previously been discussed. ${ }^{5}$

Abnormalities of complement function in chronic inflammatory conditions such as systemic lupus erythematosus are believed to reflect excessive consumption of complement by cascade reactions. ${ }^{22}$ The present results in relatives, indicating an increased risk for later development of overt inflammatory bowel disease, strongly suggest that the demonstrated complement dysfunction can be a central phenomenon, unrelated to mucosal inflammation or hypercatabolism of complement. It must, however, be pointed out that this argument is based essentially on just six abnormal findings among the relatives, although none were found among normal and disease controls. It would seem interesting to assess the incidence of this possible genetic predispositions to Crohn's disease in the normal population by studying a rather large sample. Such studies must await screening

Table 5 Families of Crohn probands ranked according to results of complement function test (release of chemotactic activity). Numbers 1 to 8: subnormal function; numbers 9 to 16: normal function.

\begin{tabular}{|c|c|c|c|c|}
\hline No & Patient's code & Relatives' code & Release of chemotactic activity & $\begin{array}{l}\text { Intestinal symptoms/complicating } \\
\text { conditions }\end{array}$ \\
\hline 1 & JO $230^{7}$ & $\begin{array}{l}\text { P: } 56 \sigma^{\prime \prime} \\
\text { S: } 28 \sigma^{\prime \prime}\end{array}$ & $\begin{array}{l}\mathbf{N} \\
\mathbf{N}\end{array}$ & $\begin{array}{l}\text { Crohn's disease } \\
\text { Diarrhoea episodes }\end{array}$ \\
\hline \multirow[t]{5}{*}{2} & \multirow[t]{5}{*}{ AME $17 q$} & P: $530^{\circ}$ & D & - \\
\hline & & P: 57 Q & D & - \\
\hline & & S: $24 \sigma^{\prime \prime}$ & $\mathbf{N}$ & - \\
\hline & & S: 24 우 & $\mathbf{N}$ & - \\
\hline & & S: $210^{\circ}$ & $\mathrm{N}$ & - \\
\hline \multirow[t]{2}{*}{3} & \multirow[t]{2}{*}{ JHH $27 \sigma^{\prime \prime}$} & P: 50 ? & $\mathbf{N}$ & - \\
\hline & & S: 24 @ & D & - \\
\hline 4 & OFR $210^{\prime \prime}$ & S: $23 \sigma^{\prime}$ & $\mathrm{D}$ & Ankylosing spondylitis \\
\hline \multirow[t]{3}{*}{5} & \multirow[t]{3}{*}{ PMB 28우 } & P: $530^{\circ}$ & $\mathbf{N}$ & - \\
\hline & & P: 549 & $\mathbf{N}$ & - \\
\hline & & S: 23 q & D & - \\
\hline \multirow[t]{3}{*}{6} & \multirow[t]{3}{*}{ MT 19q } & P: $480^{\prime \prime}$ & $\mathrm{N}$ & - \\
\hline & & P: 44 q & $\mathrm{N}$ & - \\
\hline & & S: $220^{\prime \prime}$ & $\mathrm{N}$ & - \\
\hline 7 & AW 35 Q & S: 39 Q & $\mathbf{N}$ & - \\
\hline 8 & VE 20@ & S: $23 \sigma^{\prime \prime}$ & D & - \\
\hline \multirow[t]{3}{*}{9} & \multirow[t]{3}{*}{ TW $130^{\prime \prime}$} & $\mathrm{P}: 42 \sigma^{7}$ & $\mathbf{N}$ & - \\
\hline & & $P: 389$ & $\mathrm{~N}$ & - \\
\hline & & $\mathrm{S}: 15 q$ & $\mathrm{~N}$ & - \\
\hline 10 & GFJ 37 웅 & S: $250^{\circ}$ & $\mathbf{N}$ & - \\
\hline \multirow[t]{3}{*}{11} & \multirow[t]{3}{*}{ MRH 28 운 } & P: $520^{7}$ & $\mathrm{~N}$ & - \\
\hline & & P: 529 & $\mathbf{N}$ & - \\
\hline & & S: $250^{\circ}$ & $\mathrm{N}$ & - \\
\hline 12 & LBH 28 우 & S: $340^{\circ}$ & $\mathbf{N}$ & - \\
\hline \multirow[t]{2}{*}{13} & \multirow[t]{2}{*}{ LSS $19 q^{\circ}$} & P: 39 Q & $\mathrm{N}$ & - \\
\hline & & S: $18 \sigma^{\circ}$ & $\mathbf{N}$ & - \\
\hline 14 & LSH 45 Q & S: $290^{\circ}$ & $\mathrm{N}$ & - \\
\hline 15 & LFN 139 & P: 319 & $\mathbf{N}$ & - \\
\hline \multirow[t]{3}{*}{16} & SNK 26우 & P: $550^{\circ}$ & $\mathbf{N}$ & - \\
\hline & & P: 529 & $\mathbf{N}$ & - \\
\hline & & S: 31 + & $\mathrm{N}$ & - \\
\hline
\end{tabular}

$\mathrm{P}=$ parents $; \mathrm{S}=$ siblings $; \mathrm{N}=$ normal $; \mathrm{D}=$ decreased. 
Table 6 Generation of chemotactic activity in $\mu \mathrm{m} / 45$ minutes by the alternative pathway of plasma complement. Dependence on incubation time and concentration of activating zymosan. Medians with ranges in parentheses.

\begin{tabular}{|c|c|c|c|c|c|c|c|c|c|}
\hline \multirow[b]{2}{*}{ Source of complement } & \multicolumn{5}{|c|}{ Zymosan $(g / l)$} & \multicolumn{4}{|c|}{ Incubation time (minutes) } \\
\hline & 0 & $2 \times 10^{-2}$ & $2 \times 10^{-1}$ & 2 & $2 \times 10$ & 0 & 15 & 60 & 120 \\
\hline $\begin{array}{l}\text { Series I } \\
\text { Normals }(n=6)\end{array}$ & 27 & 63 & 102 & 89 & 80 & & & $\mathbf{x}$ & \\
\hline$C D^{*}$ patients $(n=6)$ & $\begin{array}{l}25 \\
(12-36)\end{array}$ & $\begin{array}{l}(40-84) \\
26 \\
(13-46)\end{array}$ & $\begin{array}{l}45 \\
(22-68)\end{array}$ & $\begin{array}{l}(10-100) \\
55 \\
(38-64)\end{array}$ & $\begin{array}{l}(38-100) \\
62 \\
(52-70)\end{array}$ & & & $\mathbf{x}$ & \\
\hline \multicolumn{10}{|l|}{ Series II } \\
\hline Normals $(n=6)$ & & & $\mathbf{x}$ & & & $\begin{array}{l}35 \\
(17-58)\end{array}$ & $\begin{array}{l}104 \\
(52-133)\end{array}$ & $\begin{array}{l}121 \\
(86-143)\end{array}$ & $\begin{array}{l}109 \\
(62-126)\end{array}$ \\
\hline$C D^{*}$ patients $(n=6)$ & & & $\mathbf{x}$ & & & $\begin{array}{l}29 \\
(14-60)\end{array}$ & $\begin{array}{l}84 \\
(65-95)\end{array}$ & $\begin{array}{l}96 \\
(67-120)\end{array}$ & $\begin{array}{l}90 \\
(62-114)\end{array}$ \\
\hline
\end{tabular}

Series I: incubation time held constant.

Series II: zymosan concentration held constant.

* Crohn's disease $=\mathrm{CD}$.

procedures which are less time consuming than the combination of biologic and electrophoretic assays applied in the present paper. An immunoelectrophoretic method for C5a measurements may permit a valuable methodological alternative for large studies.

The possible pathogenetic significance of the complement abnormality remains to be established. Only careful clinical follow up will reveal if relatives considered at risk will ultimately develop overt disease. Complement dysfunction seems to be relatively specific for Crohn's disease probands and relatives because the present patients with ulcerative colitis and peptic ulcers all showed normal generation of chemotactic activity by complement.

As previously shown for Crohn's disease patients ${ }^{2}$ complement abnormality in the present subgroup of first degree relatives was associated with a decreased consumption of complement $\mathrm{C} 3$ by the cascade reaction. Depressed conversion at both C3 and C5 levels during activation, with resulting subnormal release of the major, complement derived chemotactic factor C5a, is probably the underlying defect. The recent demonstration of increased cell directed inhibitors of chemotaxis and of chemotactic factor inactivators ${ }^{23}$ possibly contribute to a defective chemotactic factor generation but not to the abnormality at C3 level in Crohn's disease.

The molecular basis of this deficient function of the alternative pathway remains unknown. Previous measurements of individual complement components involved and of the control proteins have been negative. ${ }^{6}$ Further studies trying to relate complement dysfunction with polymorphism of complement proteins and with established genetic markers such as the HLA-types are being done.

The subgroups of relatives with complement dysfunction comprised six persons only. Both parents/siblings and men/women were represented, but the group is too small for any statistical analysis. Complement abnormality in relatives was confined to families of patients who themselves showed similar changes. Thus, further screening of relatives could probably be confined to families of patients with complement dysfunction. Crohn's disease patients with early onset may be especially predisposed to acquire the disease by genetic and/or environmental factors. Our figures for complement abnormality in close relatives consequently may not be representative for relatives of unselected patients with Crohn's disease.

We wish to thank $\mathrm{H}$ Furhauge and $\mathrm{H}$ Kargaard for excellent technical assistance and $\mathrm{L}$ Nielsen for typing the manuscript. The study was supported by Johann and Hanne Weimann née Sedorffs foundation.

\section{References}

1 Amelio RD, Rossi P, Moli SLE, Ricci R, Montano S, Pallone F. In vitro studies on cellular and humoral chemotaxis in Crohn's disease using the under agarose gel technique. Gut 1981; 22: 566-70.

2 Elmgreen J, Berkowicz A, Sørensen H. Defective release of $\mathrm{C} 5$ a related chemo-attractant activity from complement in Crohn's disease. Gut 1983; 24: 525-31.

3 Lake AM, Stitzel AE, Urmson JR, Walker WA, Spitzer RE. Complement alterations in inflammatory bowel disease. Gastroenterology 1979; 76: 374-9.

4 Hodgson HJF, Potter BJ, Jewell DP. C3 metabolism in ulcerative colitis and Crohn's disease. Clin Exp Immunol 1977; 28: 490-5. 
5 Elmgreen J, Berkowicz A, Sørensen H. Hypercatabolism of complement in Crohn's disease. Acta Med Scand 1983; 214: 403-7.

6 Potter BJ, Brown DJC, Watson A, Jewell DP. Complement inhibitors and immunoconglutinins in ulcerative colitis and Crohn's disease. Gut 1980; 21: $1030-4$.

7 Ament ME, Ochs HD. Gastrointestinal mannifestations of chronic granulomatous disease. $N$ Engl J Med 1973; 288: 382-7.

8 Lewkonia RM, McConnell RB. Progress report. Familial inflammatory bowel disease. Heredity or environment. Gut 1976; 17: 235-43.

9 Singer HC, Anderson JGD, Frischer H, Kirsner JB. Familial aspects of inflammatory bowel disease. Gastroenterology 1971; 61: 423-30.

10 Farmer RG, Michener WM, Mortimer EA. Studies of family history among patients with inflammatory bowel disease. Clin Gastroenterol 1980; 9(2): 271-7.

11 Binder V, Both H, Hansen PK, Hendriksen C, Kreiner $\mathrm{S}$, Torp-Pedersen $\mathrm{K}$. Ineidence and prevalence of ulcerative colitis and Crohn's disease in the county of Copenhagen, 1968-1978. Gastroenterology 1982; 83: 564-8.

12 Harvey RF, Bradshaw JM. A simple index of Crohn's disease activity. Lancet 1980; 1: 544.

13 Binder V. A comparison between the clinical state, macroscopic and microscopic appearance of rectal mucosa and cytologis picture of mucosal exudate in ulcerative colitis. Scand J Gastroenterol 1970; 5: 62732.

14 Atkinson JP, Frank MM. Complement. In Parker CW, ed. Clinical Immunology. Philadelphia, London, Toronto: Saunders, 1980.

15 Wilkinson PC. Chemotaxis and inflammation. Edinburgh: Churchill Livingstone, 1974.

16 Zigmond SH, Hirsh JG. Leucocyte locomotion and chemotaxis. $J$ Exp Med 1973; 137: 387-410.

17 Bøyum A. Isolation of mononuclear cells and granulocytes from human blood. Scand J Clin Lab Invest 1968; 21: suppl 97: 77-89.

18 Teisberg $\mathrm{P}$. In vivo activation of $\mathrm{C} 3$ revealed by crossed immuno-electrophoresis as a parameter of immunologic activation in disease. Clin Chem Acta 1975; 62: 35-41.

19 Laurell CB. Quantitative estimation of proteins by electrophoresis in agarose gel containing antibodies. Anal Biochem 1966; 15: 45-52.

20 Berkowicz A, Rosenkvist J, Sørensen H. A single step immuno-electrophoresis method for the quantitation of complement $\mathrm{C} 3 \mathrm{c}$ in biological fluids. J Immunol Methods 1983; 60: 277-88.

21 Elmgreen J. Subnormal activation of phagocytes by complement in chronic inflammatory bowel disease. Neutrophil chemotaxis to complement split product C5a. Gut 1984; 25: 737-42.

22 Lawley TJ, Frank MM. Immune complexes and immune complex diseases. In: Parker CW, ed. Clinical immunology. Philadelphia, London, Toronto: Saunders, 1980.

23 Rhodes JM, Potter BH, Brown BJC, Jewell DP. Serum inhibitors of leucocyte chemotaxis in Crohn's disease and ulcerative colitis. Gastroenterology 1982; 82: 132734. 